\title{
A Survey of Cavity-Nesting Bees and Wasps in Loblolly Pine Stands of the Savannah River Site, Aiken County, South Carolina'
}

\author{
Scott Horn' and James L. Hanula
}

Southern Forestry Sciences Laboratory, U.S. Forest Service, 320 Green Street, Athens, GA, 30602 USA

\section{J. Entomol. Sci. 39(3): 464-469 (July 2004)}

Key Words Trap nests, Vespidae, Megachilidae, Sphecidae, cavity-nesting bees, cavitynesting wasps

In recent years concern over widespread losses in biodiversity has grown to include a possible decline of many native pollinators, primarily bees (Buchmann and Nabhan 1996, The Forgotten Pollinators, Island Press). Factors such as habitat fragmentation, agricultural practices, use of pesticides, the introduction of invasive species, or changes in land use may negatively impact these vital organisms (Kearns et al. 1998, Ann. Rev. Ecol. Syst. 29: 83-I 12). Most reported studies show that human impacts on pollinators are overwhelmingly negative (Vinson et al. 1993, Hymenoptera and Biodiversity, CAB International; Buchmann and Nabhan 1996). Because 60 to $70 \%$ of plant species rely on insects for pollination (Richards 1986, Plant breeding systems, Chapman and Hall), reductions in pollinator populations may profoundly impact plant population dynamics (Bond 1994, Philos. Trans. R. Soc. Lond. B. Biol. Sci. 34: 83-90). Consequently, decreases in native pollinator diversity and abundance may severely impact ecosystem function (Druess and Tscharntke 1994, Science 264: 1581-I 584; Steffan-Dewenter and Tscharntke 1999, Oecologia 121: 432-440.).

Although floral resources are clearly important to pollinator success, an equally important factor defining bee communities is the availability of nesting habitat (Barthell et al. 1998, Environ. Entomol. 27: 117-124). Despite this, Cane (2001, Cons. Ecol. 5: 3) stated that pollinator habitat "fragmentation" studies have focused on patches of flowering plants without regard to the negative impacts that losses in nesting substrates undoubtedly have on bee species. The availability of suitable nesting habitat is likely to be a major determinant of animal movement (Crist et al. 1992, Funct. Ecol. 6: 536-544; Carter and Real 1997, Oecologia 112: 430-434) and may be as important to the success of local populations as floral resources. Typically, nests are constructed within holes left by wood-boring beetles, hollowed plants stems, or in soils of appropriate texture, depth, and moisture (Cane 2001).

'Received 15 September 2003; accepted for publication 10 March 2004

*Address inquiries (shorn01@fs.fed.us). 
Wooden trap nests are a common and reliable method for surveying cavity-nesting bees and wasps and have been used widely since the 1960's (Krombein 1967, Trap-nesting wasps and bees, Smithsonian Institute). Studies using trap nests have provided important baseline data on species diversity and abundance (Parker 1986, Env. Entomol. 15: 877-879; Parker 1987, Pan-Pac. Entomol. 63: 125-129; JacobRemacle 1986, Bull. Ann. Soc. Belge Entomol. 122: 107-I 18; Beyer et al. 1987, Proc. Entomol. Soc. 89: 478-482), and evaluated the occurrence of selected species over time (Frankie et al. 1993, Biotropic 25: 322-333; Strickler et al. 1996, Pan-Pac. Entomol. 37: 89-93). Little baseline data exist on the diversity and relative abundance of bees and wasps in southern forests. The objective of this study was to develop a simple, effective method of surveying cavity-nesting bees and wasps and to determine species diversity in mature forests of loblolly pine (Pinus taeda L.), the most widely planted tree species in the southern United States.

Our study plots were located on the Savannah River Site (SRS) near Aiken, SC. The SRS is a United States Department of Energy facility where the surrounding land is managed as a national environmental research park. The SRS is in the upper Atlantic Coastal Plain. The forests on the SRS are dominated by even-aged stands of loblolly, longleaf ( $P$. palustris Miller), and slash pine ( $P$. elliottii Engelm.). The plots used were 9 ha in size and consisted of an overstory of 45 to 50 -yr-old planted loblolly pines. The midstory was predominantly mockernut hickory (Carya tomentosa Nuttall), sweetgum (Liquidambar styraciflua L.), and wax myrtle (Myrica cerifera L.). Understory plants varied between plots but commonly encountered species included poison oak (Rhus toxicodendron L.), Carolina jessamine (Gelsemium sempervirens St.-Hil.), fox grape (Vitis aestivalis Michaux), and bicolor lezpedeza (Lezpedeza bicolor Turcz.).

Trap nest blocks were created by drilling 5 holes of each of three diameters (7.9, $6.0,4.4 \mathrm{~mm})$ into $3.8 \times 8.9 \times 30 \mathrm{~cm}$ sections of untreated kiln-dried wood $(5 \times 10 \mathrm{~cm})$ (Fig. 1). Holes were $7.5 \mathrm{~cm}$ deep and drilled approximately $0.75 \mathrm{~cm}$ apart in the 3.8 $\mathrm{cm}$ side of the blocks in a repeating series of largest to smallest. Hole sizes were chosen to be consistent with previously published reports (Krombien 1967) and measurements of wood borer exit holes in several loblolly pine logs ( $n=92$ holes) present at the site. Sections of $1.27 \mathrm{~cm}$ diam EMT electrical conduit supported the blocks approximately $1.2 \mathrm{~m}$ above ground. Traps were placed in the central part of the plots. Five trapping locations were selected at $30-\mathrm{m}$ intervals along a line through the center of each plot. Two traps were spaced $5 \mathrm{~m}$ apart at each trapping location so that we had a total of 10 blocks per plot for a total of 80 traps on 8 plots. Traps were deployed from 12 April to 9 May and 1 August to 29 August 2002. Poles were sprayed with Tangle Trap@ sticky adhesive at the beginning of each trapping period to reduce nest predation by crawling arthropods.

At the end of each sampling period, trap nest blocks were collected, returned to the laboratory, and placed in an environmental chamber (12L:12D;60\% RH and $25^{\circ} \mathrm{C}$ ) to rear adults. Prior to rearing, each occupied block was x-rayed to determine the number of cells in each nest. Blocks were placed individually into mailing tubes $(10 \mathrm{~cm}$ diam; $40 \mathrm{~cm}$ long) with a 4-dram glass vial inserted into a hole at one end where emerging bees or wasps were preserved in $70 \%$ ethyl alcohol. Adults began emerging within 2 wks. Blocks remained in the environmental chamber for 2 months. After 2 months, blocks from the August sample were placed outside to experience normal cold temperatures for 3 months (Nov-Jan 2002). After cold treatment, the tubes were placed back into the chamber for an additional 2 months. Specimens were stored in 


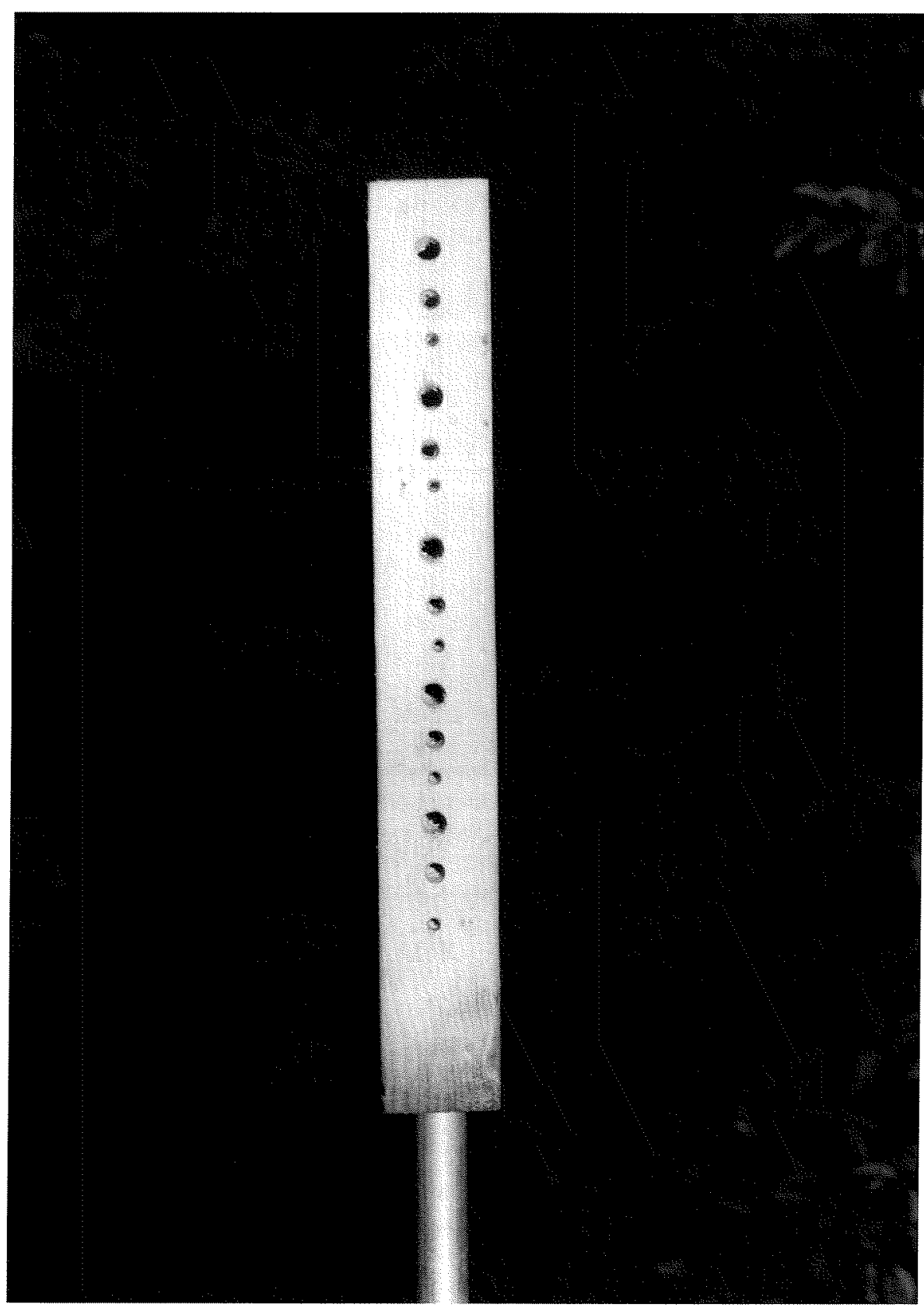

Fig. 1. Trap nest used for sampling cavity-nesting bees and wasps. Blocks of wood with holes of three different diameters were erected on $1.2 \mathrm{~m}$ tall metal poles which kept the block from being disturbed by mammals. 
Table 1. Total number of individuals of each species caught during each sample period and sex ratios reared from trap nests

\begin{tabular}{|c|c|c|c|c|}
\hline Family & Species & Total collected (sex) & May & August \\
\hline Vespidae & Euodynerus annectens (Saussure) & $135(77 \mathrm{~m} / 58 \mathrm{f})$ & 115 & 20 \\
\hline Vespidae & Parancistrocerus bicornis caenothi (Rohwer) & $12(5 \mathrm{~m} / 7 \mathrm{f})$ & 9 & 3 \\
\hline Vespidae & Parancistrocerus salcularis salcularis (Saussure) & $11(6 m / 5 f)$ & 10 & 1 \\
\hline Megachilidae & Megachile mendica Cresson & $78(45 \mathrm{~m} / 30 \mathrm{f})$ & 73 & 5 \\
\hline Megachilidae & Megachile inimica sayi Cresson & $5(3 \mathrm{~m} / 2 \mathrm{f})$ & 0 & 5 \\
\hline Megachilidae & Coelioxys slossoni arenicola Crawford & $5(5 m)$ & 5 & 0 \\
\hline Megachilidae & Osmia atriventris Cresson & $1(1 \mathrm{~m})$ & 0 & 1 \\
\hline Megachilidae & Stelis costalis costalis Cresson & $2(1 \mathrm{~m} / 1 \mathrm{f})$ & 0 & 2 \\
\hline Sphecidae & Trypargilium tridentatum Packard & $52(13 m / 39 f)$ & 2 & 50 \\
\hline Sphecidae & Trypargilium clavatum Say & $7(4 \mathrm{~m} / 3 \mathrm{f})$ & 0 & 7 \\
\hline Anthophoridae & Xylocopa virginica virginica (L.) & $1(1 f)$ & 1 & 0 \\
\hline Chrysididae & Chrysis coerulans Fabricuius* & $8(5 \mathrm{~m} / 3 \mathrm{f})$ & 8 & 0 \\
\hline Chrysididae & Chrysis bequaerti $^{\star}$ Bohart ${ }^{\star *}$ & $1(1 f)$ & 1 & 0 \\
\hline Eulophidae & Melittobia sp. ${ }^{* *}$ & $1(1 f)$ & 0 & 1 \\
\hline Bombyliidae & Anthrax sp. ${ }^{*}$ & $2(?)$ & 0 & 2 \\
\hline
\end{tabular}

* Represents new host record.

** Parasites of cavity-nesting bees. 
$70 \%$ alcohol and sent for identification and voucher deposition to the Entomological Museum, Department of Biology, Utah State University and at the USDA-ARS Bee Biology and Systematic Laboratory Collection in Logan, UT.

A total of 321 bees, wasps, and flies was reared from trap nest blocks representing 7 families, 11 genera, and 15 species (Table 1). Four species were parasites of cavity-nesting bees or wasps, and another, Coelioxys slossoni arenicola Crawford, which was a cleptoparasitic megachilid that parasitizes members of the same family. Vespidae were the most common cavity nesters reared from our blocks $(49 \%$ of total catch), but Megachilidae (28\% of total catch) were more diverse (5 species). The vespid, Euodynerus annectens (Saussure), was the most common species accounting for $42 \%$ of total reared adults. Megachile mendica Cresson (Hymenoptera: Megachilidae) and Trypargilium tridentatum Packard (Hymenoptera: Sphecidae) also were common species accounting for $24 \%$ and $16 \%$ of total reared adults, respectively. The ratio of males to females was skewed towards males for the two most common species, E. annectens and M. mendica, while the third, T. tridentatum, had more females.

Although we collected 4 species in relatively high numbers, the majority of the species reared from our blocks occurred in low numbers (Table 1). Six of the 11 non-parasitic species had 7 or fewer individuals. The reasons for low numbers of some species are probably varied. The blocks themselves may not have been suitable for some species. For example, only one carpenter bee, Xylocopa virginica virginica (L.), was reared from the blocks probably because the blocks were not ideal nesting sites for this species because of either hole size or orientation. Other factors

Table 2. Number of holes used and cells present for the three sizes of entrance holes provided. Percentage of holes used in relationship to availability listed in parentheses. For cells, the number in parenthesis represents the percentage that each size hole made up of the total cells present

\begin{tabular}{lccc}
\hline & May 2002 & August 2002 & Totals \\
\cline { 2 - 4 } Category & No. used/total (\%) No. used/total (\%) No. used/total (\%) \\
\hline Blocks used & $34 / 80(43)$ & $30 / 80(38)$ & $64 / 160(40)$ \\
Number of holes used & & & \\
Large & $90 / 400(23)$ & $35 / 400(9)$ & $125 / 800(16)$ \\
Medium & $53 / 400(13)$ & $43 / 400(11)$ & $96 / 800(12)$ \\
Small & $34 / 400(9)$ & $19 / 400(5)$ & $53 / 800(7)$ \\
Total & $167 / 1200(14)$ & $97 / 1200(8)$ & $264 / 2400(11)$ \\
Number of cells & & & 3861690 \\
Large holes & $2941447(66)$ & $92 / 243(38)$ & $206 / 690(30)$ \\
Medium holes & $89 / 447(20)$ & $117 / 243(43)$ & $98 / 690(14)$ \\
Small holes & $64 / 447(14)$ & $34 / 243(14)$ & 690 \\
Total & 447 & 243 &
\end{tabular}


also may contribute to fluctuations in species abundances such as extreme weather, competition with exotic species, or marginal habitats resulting from natural or manmade actions (Frankie et al. 1998). Others may occur naturally in low numbers throughout their range. We hope long-term sampling of these plots will yield information on species diversity and abundance over time and how they respond to forest management in loblolly forests.

Cavity-nesters utilized approximately $40 \%$ of the blocks each trapping period (range was 0 to $100 \%$ use/plot) and $11 \%$ of the total holes provided (Table 2). There was slightly more use of blocks ( 43 vs $38 \%$ ) and holes (15 vs $8 \%$ ) during the spring season than the later trapping season. During the early trapping period, cavity-nesting bees and wasps nested more frequently in larger diameter holes $(7.9 \mathrm{~mm})$. However, later in the year the large and medium diameter holes were used in approximately equal proportions. Vespidae and Megachilidae, which used the larger holes, were more common in the spring while Sphecidae that used the medium diameter holes were more abundant during the second sampling period. We measured 92 naturally created woodborer holes in logs and found the average diameter was $6.2 \mathrm{~mm}$ (range 4 to $9 \mathrm{~mm}$ ), which was almost the same as our medium diameter holes. During the May sample period, X-rays revealed 3.3 provisioned cells/hole compared to 1.7 and 1.9 cells/hole for medium and small holes, respectively. During the August sample large and medium diameter holes had the same number of cells per hole. The differences in numbers of cells/hole were probably due to the different species nesting in them. In the spring, megachilids were more common and they placed more cells per hole compared to vespids which were relatively more abundant in summer.

We thank Danny Dyer and Michael Ulyshen for help in the field, Michael Cody for assistance using the X-ray machine, and James Pitts for species identifications. This research was supported by the Department of Energy, Savannah River Operations Office through the USDA Forest Service. The Savannah River Site is a National Environmental Research Park. This article is for the purpose of information and reports original research. The mention of product names does not constitute an endorsement by the USDA Forest Service. 